\title{
不純物診断用空間分解真空紫外分光器の新提案
}

\author{
水井順一, 佐藤国憲
}

(名古屋大学プラズマ研究所)

( 1985 年 4 月 5 日受理)

\section{Proposal of Space-resolved Vacuum Ultraviolet Spectrometer for Impurity Diagnostics}

\author{
Jun-ichi Mizui and Kuninori Sato
}

(Received April 5, 1985)

\begin{abstract}
A simple spectrometer is designed in which a transmission grating is adopted to disperse vacuum ultraviolet radiation and space resolution is achieved by using an aperture of the grating as a one-dimensional analog of a pin hole camera. Wave length resolution is calculated to be less than $5 \mathrm{~A}^{\circ}$.
\end{abstract}

\section{1. 序論}

最近のトカマク装置に代表される大型磁気閉じ込め装置においては, プラズマ内の不純物イオンの研究が 重要視されている ${ }^{1,2)}$ 。乙れらの不純物イオンは, プラズマからの輻射損失に寄与するばかりでなく, 例えば 平均イオン電荷数に関連した輸送係数である電気抵抗が変わるてとで, プラズマ電流の半径方向分布も支配 する要因となっている。従って不純物イオンは, 単に減らせば良いと言うものでなく, てれらの輸送係数や プラズマ・パラメーターを適当な半径方向分布とするためのプラズマ制御の手段としても考えられている。 一方不純物イオンの拡散係数の值は, 実験とシミレーションの比較から経験的に評価されているが, 物理的 内容の理解は不満足であると思われる。実験側からてれらの現象をより深く理解するためには, 不純物イオ ンからの線スペクトルの時間・空間分解計測が必要であり, 現在まで種々の方法が実行されてきた。

この報告では, 透過型回析格子とピンホール・カメラを組み合わせた方式による簡潔な新計測法を提案す る。 2 章では従来の計測法と新計測法の定性的な比較をする。 3 章では分光器の各要素に対する基本関係式

Institute of Plasma Physics, Nagoya University, Nagoya 464. 
と許容パラメーター範囲を論ずる。4 章では設計例とてれによる計測可能なイオン線スペクトルについて述 べる。

\section{2. 真空紫外光用空間分解分光法}

トカマク・プラズマに応用可能な真空紫外光用空間分解分光法を分類すると以下の様になる。

(1) プラズマ放電の各ショット毎に, 斜入射分光器を上下動, または傾けるととにより, 観測位置を変え て空間分布を得る。

(2) 斜入射分光器とプラズマの間に, 斜入射型ミラーを設定し, てれをプラズマ放電の持続時間内に速く 回転する ${ }^{3)}$ 。

(3) 斜入射分光器とプラズマの間に, または斜入射分光器内に, ピンホール・カメラの原理に従って第 2 スリットを(れる ${ }^{4,5,6)}$ 。 1

(4) 透過型回折格子分光器に, (3) と同様な空間分解用スリットを入れる ( 本報告での設計例 )。 これらの方式を比較すると，(1)はプラズマ放電の再現性に依存するので望ましくない。また一組みのデータ 一をとるために多数のショットを必要とする。(2)はプラズマ放電と同期を取ってうラーを回転できない。 時間分解幅が数ms 以下にはならない。さらに斜入射型ミラーは回転角に制限があり, 大きなプラズマ全体 を計測するためにはシステムの長さが増大する。例えば回転角は約 4 度であり ${ }^{3)}$, プラズマの直径を $40 \mathrm{~cm}$ とすると,プラズマから回転ミラーまでの距離は約 $570 \mathrm{~cm}$ となるまたてのミラーの真空紫外光に対する 反射率を評価する必要がある。次に(3)の方式はレーザー・プラズマで最初に応用されたもので, 波長分解 用入りロスリットと直交させて空間分解用第 2 スリットを分光器内の回折格子の前に設定したものである ${ }^{4}$ 。 斜入射分光器内の各要素の位置設定精度が要求されるととと収差等を考慮するため, 計算機による光線追跡 により，大きなプラズマに対して充分な検討を行う必要がある。(2)に比べて，(3), (4)の方式は, ピンホール・ カメラの原理に従って結像立体角が大きなとと。結像系に対する反射率等の較正が不要。さらに可動部が少 ないため計測が安定している利点がある。最後に(4)の方式は, 回折格子が真空紫外に対して直入射で使用 できるため, 位置設定精度が要求されず, 最も簡便なシステムである。又 $10 \mathrm{~A}^{\circ}$ 以上の波長で回折効率の実 測值が, 幾何光学計算值とほぼ一致しており, 表面状態によらず, 経年変化はないと思われる7）。しかし後 の設計例でも示すように, 装置幅 ( 分解波長幅) $\Delta \lambda=2.5 \sim 5 \mathrm{~A}^{\circ}$ と,(3)の方式よりは劣る。従って結論 的に言えば, 本格的分光法で波長精度を要求する場合, (3)の方式が適当であり, プラズマ実験者が，簡便な 空間分解専用計測を考光る場合, (4)の方式が適当と考える。

空間分解分光計測を行う時, さらに考虑しなければならない点として, 検出器の問題がある。特に(3)と

*1 とれら 4), 5) の分光器はレーザー・プラズマ用で, 時間分解は行っていない。また6)の分光器 は斜入射方式ではなく, 波長域は $300 \sim 1700 \mathrm{~A}^{\circ}$ である。 
(4)の方法では, 波長と空間の 2 次元的な情報を同時処理できれば理想的である。これが可能な検出器として MCP (microchannel plate ) があり, 最近使用例が多くなっている ${ }^{6,8)}$ 。 MCP 用いるためには分光 器の出力焦点面が平面であるととが望ましく, ホログラフィク回折格子 ${ }^{8)}$, 数值制御機械刻線回折格子 ${ }^{9}$ 等 にょりとの条件が達成されている。しかしての特殊な回折格子を用いた空間分解分光はまだ行われていな い。前述のように, このための設計では, 回折格子を熟知した者が光線追跡により充分な検討を行う必要 がある。勿論, 結像系を用いない透過型回折格子の出力面を平面とするととに問題はない。次に時間分解の 良い検出器列を, ある波長において空間分解の方向に設定すると, 軟X線トモグラフィーの技術が応用でき る。この技術で円筒対称を仮定しないでプラズマ内の軟X線分布が計測され，プラズマ中の不安定性との関 連が研究されている ${ }^{10,11)}$ 。さらに分光へのトモグラフィー技術の応用により, プラズマ中での不純物イオ ンや粒子の輸送現象と, プラズマの不安定性の関連が解明される可能性があると思われる。以上の考察から 透過型回折格子を用いた空間分解分光器の設計において，MCP を用いる形式と，トモグラフィー技術の応用 を想定した電子増倍管列（またはセラトロン列）を用いる形式を検討した。MCPを用いたトモグラフィー技術 の応用も考えられるが, 設計としては, 前者は縮小倍率, 後者は拡大倍率を検討したと考えている。

\section{3. 各要素の設定配置と基本関係式}

プラズマに対して設定された分光器の各要素の配置を図 1 亿示す。大きなプラズマを対象として波長分解 精度を高めるため, プラズマと回折格子の間に, 格子の方向と平行なスリットを入れ, その幅と回折格子の 使用幅を同じ $S_{\lambda}$ と設定する*2。 回折条件は, よく知られた関係式,

$$
\sin \alpha+\sin \beta=n \lambda / a
$$

において, 入射角 $\alpha \sim 0$, 格子定数 $a=0.333 \mu_{\mathrm{m}}(30001 / \mathrm{mm})$, 使用最大波長 $\lambda \max =600 \mathrm{~A}^{\circ}$, 回 折次数 $\mathrm{n}=1$ とすると, 回折角 $\beta$ は, $\sin \beta=0.180$ であるから， $\beta=10.4^{\circ}$ となる。従って (1)式は近似的に

$$
\beta=n \lambda / a, \Delta \beta=n \cdot \Delta \lambda / a
$$

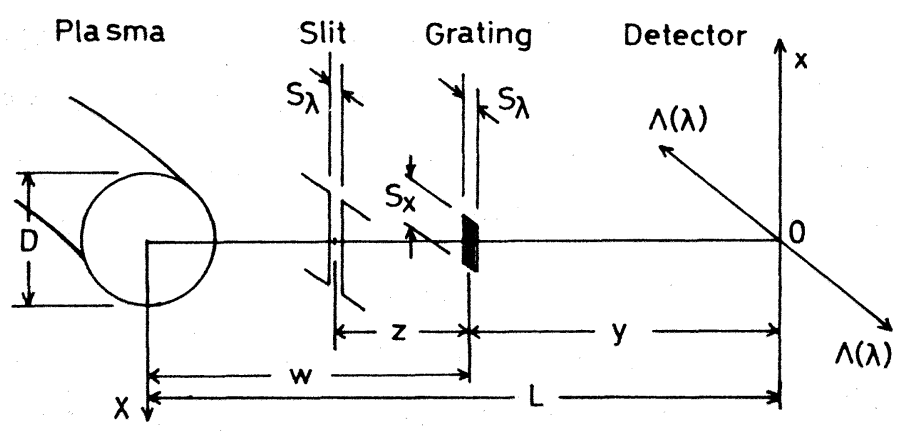

図 1.プラズマと分光器の各要素の配置。

$\mathrm{S}_{\lambda}$ ：波長分解スリット幅， $\mathrm{S}_{\mathrm{x}}$ ：空間分解スリット幅。

*2 スリット幅 $\mathrm{S}_{0}$ と回折格子幅 $\mathrm{S}_{\lambda}$ が異なる場合, (3) 式は $\Delta \boldsymbol{\Lambda}=\mathrm{S}_{\lambda} \cdot\left[1+\left(1+\mathrm{S}_{0} / \mathrm{S}_{\lambda}\right) \boldsymbol{y} / \boldsymbol{z}\right]$ とな る。従って $\mathrm{S}_{0}$ が小さい方が良い。しかし $\mathrm{S}_{0}=0$ で, $y$ の大きい図 3 の例でも, $\Delta \lambda$ は $5 \mathrm{~A}^{\circ}$ が $4 \mathrm{~A}^{\circ}$ となる程度である。 $\mathrm{S}_{0}$ を変えると分光強度が変わるので, $\mathrm{S}_{x}$ と同様に可変とすれば良い。 
としてよい。装置幅 $\Delta \lambda$ を決める広がり角 $\Delta \beta$ は, 2 枚の平行スリットに入射する単色光線が, 検出面上に つくる最大の像の広がり $\Delta \boldsymbol{\Lambda}$ により決まる。ただし回折を受けない 0 次光も, 回折を受ける 1 次光, 2 次光, …等も, 同じ広がりとなるととから, 0 次光で幾何学的に考察すると,

$$
\Delta \Lambda=S_{\lambda} \cdot(1+2 y / z)
$$

となる。ただし， $y, z$ は，それぞれ回折格子から検出面, 回折格子からスリットまでの距離である。いま, $\Delta \Lambda=y \cdot \Delta \beta$ であるから，(2)式を用いて，

$$
\Delta \lambda=S_{\lambda} \cdot a / n \cdot(1+2 y / z) / y
$$

と表わせる。とれが設定配置で決まる装置幅である。同様な考察はレーザー・プラズマ用に行われた例が

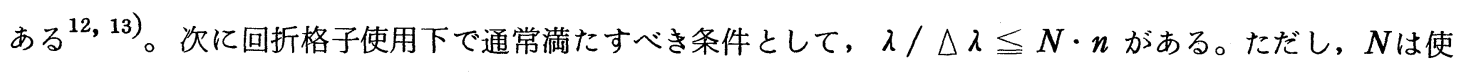
用する回折格子の総本数であり, 我々の設定では, $S_{\lambda}=N \cdot a$ となるので,

$$
S_{\lambda} \geqq a / n \cdot \lambda \max / \Delta \lambda
$$

の条件を満たす必要がある。検出面上の $n$ 次回折による分散の最大幅は,

$$
\Lambda \max =y \cdot n / a \cdot \lambda \max
$$

となる。

一方空間分解用スリットとしては図 1 に示すように, 回折格子の使用幅を $S_{x}$ として, プラズマ小半径方 向に空間を分解する。ピンホール・カメラの幾何光学的考察から, プラズマ上の空間分解 $\triangle \mathrm{X}$ と, てれに対 応する検出面上の幅 $\Delta \mathrm{x}$ は,

$$
\begin{aligned}
& \Delta \mathrm{X}=S_{x} \cdot(1+1 / M), \\
& \Delta \mathrm{x}=S_{x} \cdot(1+M)
\end{aligned}
$$

と表わせる。ただし, $M=y / w=\mathrm{x} / \mathrm{X}$ は, 検出面上でのプラズマ像の倍率である。ことで, $w$ はプラズ マ中心から回折格子までの距離である。

心要な基本関係式は以上であるが, トカマク等の大きなプラズマを対象としているため, 実際上の制約条 件としてDをプラズマの大きさとすると， $w-z>\mathrm{D} / 2$ 。さらに計測器の長さ $\mathrm{L}=w+y$ は適当に小さい ととが望まれる。とのような制約条件も考慮して最適設計を行うために，適当な仮定をして考察を進める。 まず, (5)式の不等式は,

$$
S_{\lambda}=2 \cdot a / n \cdot \lambda \max / \Delta \lambda
$$

とし, $\phi=n \cdot \Delta \lambda / a$ と定義すると,

$$
S_{\lambda}=2 \cdot \lambda \max / \phi
$$


となる。又 $(3) ，(4) ，(8)$ 式から，

$$
\begin{aligned}
& y=\Delta \Lambda / \phi \\
& z=\frac{2 \cdot \Delta \Lambda}{\phi(\Delta \Lambda \cdot \phi / 2 \lambda \max -1)} \\
& w=y / M=\Delta \Lambda / \mathrm{M} \phi
\end{aligned}
$$

が得られる。従って制約条件を $w-z \geqq D ，(>D / 2)$ とすると，（10)，(11) 式から,

$$
\frac{\Delta \Lambda}{M \phi}-\frac{2 \cdot \Delta \Lambda}{\phi(\Delta \Lambda \cdot \phi / 2 \lambda \max -1)} \geqq \mathrm{D}
$$

が得られる。又計測器の長さ L 亿対して,

(9), (11) 式方ら,

$$
\Delta \Lambda=L \phi /(1+1 / M)
$$

となる。最後に検出器の使用条件として, $\mathrm{MCP}$, 電子増倍管列の二例を考える。

例 I. MCP

$$
\text { プラズマの大きさ } \mathrm{D}=40 \mathrm{~cm} \text { とし, }
$$

$\mathrm{MCP}$ の大きさ $\mathrm{d}=4 \mathrm{~cm}$ とすると，

$$
\mathrm{M}=\mathrm{d} / \mathrm{D}=0.1 \text { となる。 }
$$

例 II . 電子堌倍管列

電子増倍管の直径を $3 \mathrm{~cm}$ とし, チャンネル数を 20 とすると, $\mathrm{d}=$ $60 \mathrm{~cm}$, 従って $\mathrm{M}=1.5$ となる。

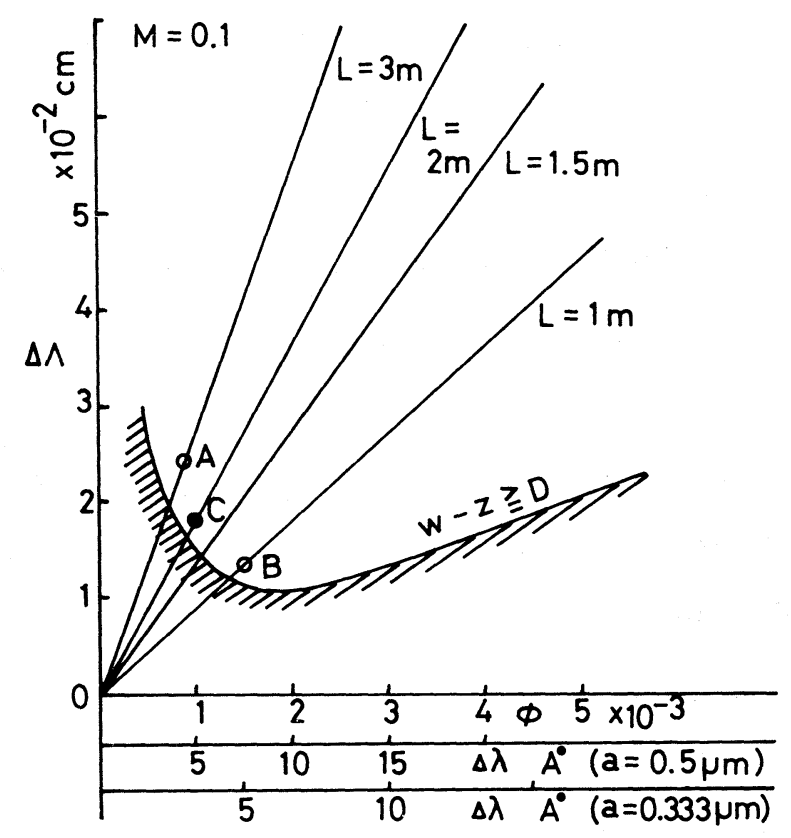

例 I と例 II に対して，(12），(13)式を用 いて, $\Delta \Lambda$ と申のパラメータ一範囲を図示 したものが，それぞれ図 2 と図 3 である。 ここで $\lambda \max =600 \mathrm{~A}^{\circ}$ とした*3。脚注 2 では, $\mathrm{a}=0.333 \mu_{\mathrm{m}}(3000 \mathrm{1} / \mathrm{mm})$ を

図 2. 空間像倍率 $M=0.1$ の場合の, 装置幅 $\Delta \lambda$ とこれに対応した 検出面上の幅 $\Delta \Lambda$ のパラメーター範囲。 $\lambda_{\max }=600 \mathrm{~A}^{\circ}$, プ ラズマ径 $D=40 \mathrm{~cm} 。 \phi=n \cdot \Delta \lambda / a, n$ : 回折次数 $(\Delta \lambda$ の 表示では $n=1$ とした), a: 格子定数。し：計測器の長さ。 $w, z$ は図1参照。

*33 使用最大波長は, 回折格子の開口幅 $(a-c)$ と格子厚さ $b$ にる制限で決まる。ただし, $c$ は格子 幅。開口比 $m=(a-c) / a$ は分光強度にも関連して重要なパラメーターである。てれらを用いる と, $\beta \max =n \lambda \max / a=(a-c) / b=\mathrm{m} a / b$, つまり $\lambda \max =a^{2} / n \cdot m / b$ となる。従って例え ば $a=0.333 \mu \mathrm{m}, n=1, m=0.3, b=0.35 \mu \mathrm{m}$ とすると, $\lambda \max =950 \mathrm{~A}^{\circ}$ である。 


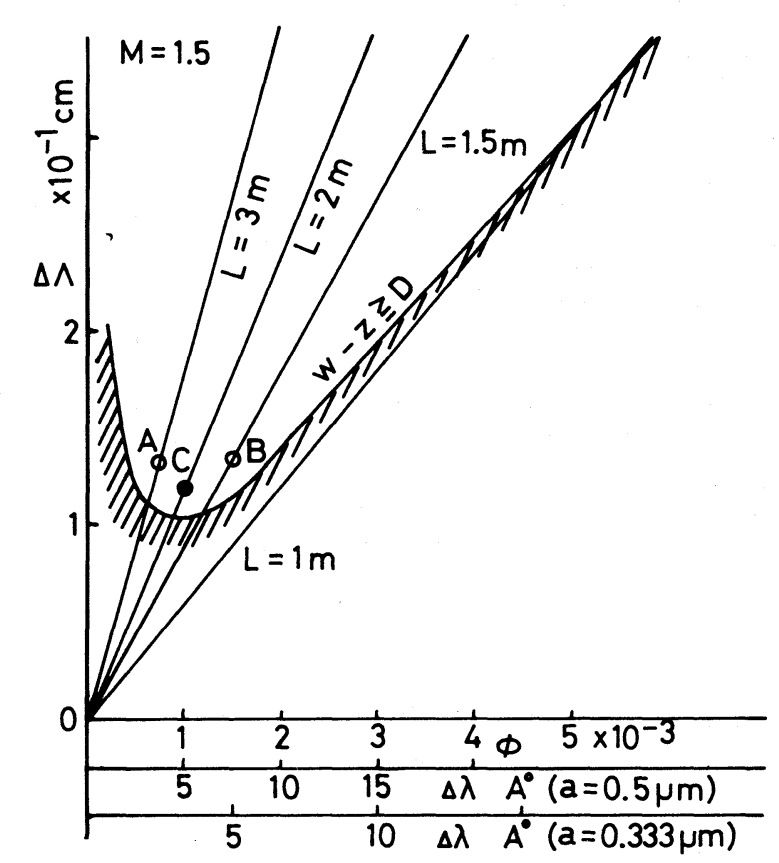

図 3. 空間像倍率 $M=1.5$ の場合の $\Delta \lambda$ と $\Delta \Lambda$ のパラメーター

範囲。条件等は図 2 と同じ。

使用しており, 又 $\mathrm{a}=0.5 \mu \mathrm{m}(2000 \mathrm{l} / \mathrm{mm})$ の回折格子は市販されており, 図の横軸には $\mathrm{n}=1$ とし て対応した $\Delta \lambda$ が表示してある。てれらの図から， $\Delta \lambda$ をさくするためにはLが大きくなり，比較的コン

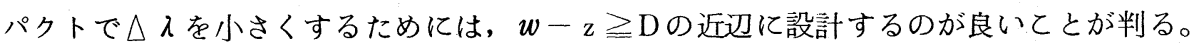

\section{4. 設計例と線スペクトルの波長選択}

図 $2 ， 3$ 中の, A , B , C と表示したパラメーターで設計した例を表 1 亿示す。Aは, 格子定数 $\mathrm{a}=0.333$ $\mu \mathrm{m}(30001 / \mathrm{mm})$ で, 装置幅 $\triangle \lambda$ をできるだけ小さくした場合, Bは, 同じ格子で, 測定器の長さLを 小さく設定した場合， Cは, 格子定数として $\mathrm{a}=0.5 \mu \mathrm{m}(20001 / \mathrm{mm})$ を使用した場合である。空間分 解 $\triangle \mathrm{X}$ に関しては詳しい考察をしなかったが，(7)式から判るように, $\Delta \mathrm{X}=0.1 \sim 1 \mathrm{~cm}$ 亿対して, $\mathrm{S}_{\mathrm{x}}=$ $90 \sim 900 \mu_{\mathrm{m}}(\mathrm{M}=0.1$ の場合 $)$ ，または $\mathrm{S}_{\mathrm{x}}=600 \sim 6000 \mu_{\mathrm{m}}(\mathrm{M}=1.5$ の場合）と余裕がある。従っ て分光強度を調整するためにも, 可変スリット機構を導入するのが適当と考光られる*2。

設計例から, $\Delta \lambda$ は 2.5 $5 \mathrm{~A}^{\circ}$ である。波長域 $\lambda=\Delta \lambda \sim 600 \mathrm{~A}^{\circ}$ において, 設計值 $\Delta \lambda=5 \mathrm{~A}^{\circ}$ として, 分離できるイオン線スペクトルを, 標準的なトカマク・プラズマにおいて選択したものが表 2 である1)。 $\lambda=\Delta \lambda \sim 20 \mathrm{~A}^{\circ}$ にある多価イオン線 $(\mathrm{F} \mathrm{eXVII} \mathrm{XX,} \mathrm{O} \mathrm{VII} \mathrm{UII})$ は分解できない。又 $\lambda=43 \sim 70 \mathrm{~A}^{\circ}$ にあ 
表 1. 透過型回折格子による空間分解分光器の設計例

\begin{tabular}{l|c|c|c|c|c|c}
\hline \multicolumn{1}{c|}{ 型 式 } & I-A & I-B & I - C & II - A & II-B & II - C \\
\hline$M$ & 0.1 & 0.1 & 0.1 & 1.5 & 1.5 & 1.5 \\
$\mathrm{a}(\mu \mathrm{m})$ & 0.333 & 0.333 & 0.5 & 0.333 & 0.333 & 0.5 \\
$\Delta \lambda\left(\mathrm{A}^{\circ}\right)$ & 3 & 5 & 5 & 2.5 & 5 & 5 \\
$L(\mathrm{~m})$ & 3 & 1 & 2 & 3 & 1.5 & 2 \\
$\mathrm{w}(\mathrm{cm})$ & 273 & 90.9 & 182 & 120 & 60 & 80 \\
$\mathrm{Z}(\mathrm{cm})$ & 65.0 & 25.9 & 70.6 & 48.4 & 11.3 & 26.7 \\
$\mathrm{~S}_{\lambda}(\mu \mathrm{m})$ & 133 & 80.0 & 120 & 160 & 80.0 & 120 \\
$\Delta \Lambda(\mathrm{mm})$ & 0.245 & 0.136 & 0.182 & 1.35 & 1.35 & 1.20 \\
$\Lambda_{\max }(\mathrm{cm})$ & 4.90 & 1.63 & 2.20 & 32.4 & 16.2 & 14.4 \\
\hline
\end{tabular}

註） $\mathrm{M}$ ：空間像倍率， a : 格子定数， $\Delta \lambda$ : 装置幅，L：計測器の長さ， w：プラズマから回折格子までの距離, $z$ : スリットから回折格子までの距離, $s_{\lambda}$ : 回折格子の波長方向使用幅, $\Delta \Lambda$ : 検出面上での $\Delta \lambda$ に対応した 幅, $\Lambda_{\text {max }}$ : 検出面上での $\lambda_{\text {max }}=600 A$ に対応した回折光の位置。回折次数 $n=1$, プラズマ径 $D=$ $40 \mathrm{~cm}$ とした。

表 2.トカマク・プラズマからの不純物線スペクトル において, 装置幅 $\Delta \lambda=5 \mathrm{~A}^{\circ}$ の測定で, 強度 の大きい孤立線スペクトルとして観測される代 表的なもの。1)

\begin{tabular}{|c|c|c|}
\hline イオン種 & 電離電圧 (eV) & 波長 $\left(\mathrm{A}^{\circ}\right)$ \\
\hline O VII & 739 & $21.6,21.8$ \\
\hline $\mathrm{C} \mathrm{V}$ & 490 & 33.7 \\
\hline $\mathrm{C} \mathrm{V}$ & 392 & 40.3 \\
\hline $\mathrm{Fe} X$ VIII & 1358 & 93.9 \\
\hline $\mathrm{Ti} \mathrm{XV}$ & 940 & 140.3 \\
\hline $\mathrm{OV}$ & 113.9 & 203.8 \\
\hline Fe X N & 392.2 & 211.3 \\
\hline $\mathrm{Fe} X \mathrm{~N}$ & 392.2 & 219.1 \\
\hline $\mathrm{Ni} \mathrm{X}$ VI & 570 & 249.2 \\
\hline $\mathrm{Ti} \times \mathrm{X}$ & 1425 & 259.0 \\
\hline $\mathrm{Fe} \mathrm{X} \mathrm{V}$ & 457 & 284.2 \\
\hline $\mathrm{Ni} \mathrm{X}$ VIII & 607.2 & 292.0 \\
\hline $\mathrm{FeX} \mathrm{VI}$ & 489 & 335.4 \\
\hline $\mathrm{Fe} \mathrm{X} \mathrm{V}$ & 489 & 360.8 \\
\hline $\mathrm{ON}$ & 77.4 & 554 \\
\hline
\end{tabular}

る疑似連続線も内部構造を分離できない。さ らに入=150〜200 $\mathrm{A}^{\circ}$ にある $\mathrm{Fe}, \mathrm{O}, \mathrm{Ni}$ の イオン線も比較的密集しており，てれも区別 できない。その他の領域から選択したものが 表 2 である。実際の実験においては,リミ夕 一, 注入ガス等によって変化するので, 高分 解能の他の分光器によって前もって波長分布 を調べる必要がある。実用上からはすべての 多価イオン線を検出する必要はなく, 電離電 圧の大きさに従って適当な線スペクトルを選 定するならば, $\Delta \lambda=5 \mathrm{~A}^{\circ}$ でも充分有用な 分光システムと考えられる。

又, 透過型回折格子では分散次数による回折効率の変化が大きく, 一次に対して二次の強度は約 10 分の 1,3 次はさらに弱いので), 波長選択における考察が容易になると思われる。

\section{5. 結 論}

不純物計測用の簡便な空間分解分光器として, 透過型回折格子を用いたシステムを設計した。設定条件と して, $\lambda \max =600 \mathrm{~A}^{\circ}$, プラズマ径 $\mathrm{D}=40 \mathrm{~cm}$ とした場合, 装置幅 $\Delta \lambda=5 \mathrm{~A}^{\circ}$ は容易に得られる。さらに 計測器の長さ $\mathrm{L} か ゙ ~ 3 \mathrm{~m}$ 程度となるが, $\Delta \lambda=2.5 \sim 3 \mathrm{~A}^{\circ}$ も可能である。また小形化が望まれる場合, $\mathrm{L}=1$ 〜 $1.5 \mathrm{~m}$ で設定するてとができる。検出器として MCP 用いると, 波長域 $20 \sim 600 \mathrm{~A}$ にわたって, 時間・ 
空間分解した同時情報が得られる。また検出器として電子増倍管列を二列用いると, 分散面が左右にある特 徵を利用して, 二本の不純物イオン線に対してトモグラフィー技術を応用した同時画像処理も可能であろう。

\section{参考 文献}

1) R. C. Isler : Nuclear Fusion 24 (1984) 1599.

2) 佐藤国憲 ：核融合研究 52 (1984) 472 .

3) C. Breton, C. De. Michelis, M. Finkenthal and M. Mattioli : J. Phys. E : Sci. Instrum. 12 (1979) 894 .

4) F. E. Irons and N. J. Peacock: J. Phys. B : Atom. Molec. Phys. 7 (1974) 2084.

5) J. Mizui, N. Yamaguchi, S. Takagi and K. Nishihara : Phys. Rev. Lett. 47 (1981) 1000.

6) R. K. Richards, H. W. Moos and S. L. Allen: Rev. Sci. Instrum. 51 (1980) 1.

7) H. Brauninger, P. Predehl and K. P. Beuermann: Appl. Optics 18 (1979) 368 and 2906.

8) R. J. Fonck, A. T. Ramsey and R. V. Yelle: Appl. Optics 21 (1982) 2115.

9) T. Kita, T. Harada, N. Nakano and H. Kuroda : Appl. Optics 22 (1983) 512.

10) N. R. Sauthoff, S. VonGoeler and W. Stodiek: Nuclear Fusion 18 (1978) 1445.

11) Y. Nagayama, S. Tsuji, K. Kawahata, N. Noda and S. Tanahashi : Jpn. J. Appl. Phys. 20 (1981) L 779.

12) N. M. Ceglio, R. L. Kauffman, A. M. Hawryluk and H. Medecki : Appl. Optics 22 (1983) 318.

13）水井順一, R. Sigel：核融合研究 50 , 別冊その 1 （1983） 8 . 